Marquette University

e-Publications@Marquette

English Faculty Research and Publications

English, Department of

$1-1-2005$

\title{
Austin Clarke and the Consolations of Irish Catholicism
}

Tyler Farrell

Marquette University, tyler.farrell@marquette.edu

Published Version. New Hibernia Review, Vol. 9, No. 4 (Winter 2005): 113-128. DOI. (C) 2005

University of St. Thomas. Used with permission.

Tyler Farrell was affiliated with the University of Dubuque at the time of publication. 


\section{Tyler Farrell}

\section{. \\ Austin Clarke and the Consolations of Irish Catholicism}

Allegiance to a religion often identifies the writer who chooses to display outwardly that religion's influence not only on the written word, but also on upbringing, morals, and ethical behavior. On recently discovering Joyce Kilmer's An Anthology of Catholic Poets, I wondered what it took to be included in such an anthology. Did a writer have to write about being a Catholic or compose poems that have a prayerful or soulful theme to them? Do the poems in this anthology help in understanding the otherworldly desires of Catholics? Could a writer be included in this anthology who was no longer a Catholic? I looked to the introduction for guidance. Kilmer writes,

There are in this book poems religious in theme; there are also love-songs and war-songs. But I think that it may be called a book of Catholic poems. For a Catholic is not a Catholic only when he prays; he is a Catholic in all the thoughts and actions of his life. And when a Catholic attempts to reflect in words some of the Beauty of which as a poet he is conscious, he cannot be far from prayer and adoration. ${ }^{1}$

Essentially, Kilmer is saying that writing itself is a prayerful art that uses adoration, solemnity, and joy as a source for its inspiration. Whatever is being written about is held in certain esteem and the poets included here are not only Catholic, but more accurately, view poetry as a sort of religious expression. The word "Catholic" might mean a great many things to those who label themselves such, but Kilmer seems only to be concerned with bringing together poems that happen to be written by Catholics. His definition of what a Catholic is seems to be open, considering that he includes a few poems that were written before their writers even converted to Catholicism. He wants to show writers who see the word "Catholic" from opposite or slightly askew sides. The poems that are contained in this anthology are filled with adoration and interrogation, creation and representation. In looking for a definition of "Catholic Writing," Kilmer admits that the book is filled with images shaped by the aid of memo-

1. An Anthology of Catholic Poets, ed. Joyce Kilmer (New York: Boni and Liveright, 1917), p. ix. 
ry. Whether or not these authors believe in every facet of the Catholic religion, Kilmer feels that the poetry chosen for this anthology is always dictated by "the strange memory of men living in faith."2 For Kilmer, the words "faith" and "Catholic" become interchangeable: to profess one's faith through art is a reflection of one's spirit. That faith can come in many forms, but Kilmer is mainly concerned with those writers who have chosen Catholicism, or who happen to have been raised Catholic.

Not so accidental is the fact that a great majority of the poets included in this anthology are Irish-from Joseph Campbell to Oscar Wilde, from Padraic Colum and Oliver St. John Gogarty to Thomas MacDonagh and Seamus MacManus, and of course, to Austin Clarke. While such writers as Colum and MacDonagh-two of Clarke's clear rivals at the time-often write about the joys of religion. Colum's "Christ the Comrade" MacDonagh's "Wishes For My Son: Born on St. Cecilia's Day, 1912," Clarke's "Celibacy" questions the staunch rules of Catholicism, specifically those that involve sexuality and marriage. Kilmer's choices reveal his desire to present poets who revel in their faith alongside those who question religion and the rules that govern the believers. Clarke, Colum, and MacDonagh are differently Catholic, but still fall within Kilmer's parameters for inclusion in his Anthology of Catholic Poets.

Many poets and writers have struggled with the conflict between reason and faith, and these Irish writers are no exception. James Joyce, after all, abandoned the practice of Catholicism, but it still remained a source for his autobiographical narrative because he knew that it had helped to shape his views of Ireland, of himself, and of his family and friends. "It is a curious thing, do you know, said Cranly to Stephen Dedalus, 'how your mind is supersaturated with the religion in which you disbelieve."'3 Writers who include Catholicism in their work often see it as an "ancient struggle between the need for intellectual freedom on the part of the individual and the insistence on faith as a higher authority on the part of the church."4 Kilmer's anthology was first published in Ireland in 1917, just after the Easter Rising, when political, religious, and social upheaval had reached a fever pitch.

Austin Clarke (1896-1974) employed religion to question his own ideals about life and moral or ethical behavior. It is as difficult to separate Clarke from his Catholic upbringing as it is to separate the influence of the Catholicism from the history of Ireland. Clarke continually returns to Catholicism at each stage of his writing career. It is the underlying current in his poems that also deal with

2. Kilmer, p. x.

3. Quoted in Vivian Mercier, "Mortal Anguish, Mortal Pride: Austin Clarke's Religious Lyrics," Hermathena, 4 (1974), 92.

4. Maurice Harmon, Austin Clarke: A Critical Introduction (Dublin: Wolfhound Press, 1989), p. 77. 
Irish history, with Celtic traditions, and contemporary Irish society. In many of his poems Clarke examines the issues raised by Irish Catholicism as highly complex and, certainly, particular to his specific moral upbringing. As Clarke matured, so did his sense of sin and degradation. Hampered early on by selfdoubt, he went to confession in order to come to terms with his unending sinful nature and with his rebellious thoughts against the rules and regulations of his church. We see an obvious influence of Irish Catholicism in Pilgrimage and Other Poems (1929) and recognize its super-saturation of almost every poem in Night and Morning (1938). Many of the verse plays Clarke published between 1938 reveal Clarke's catholicity, as does Ancient Lights, a small book of satires published in 1955. Later in his career Mnemosyne Lay in Dust (1966) became a focal point for Clarke's treatment of Catholicism through his autobiographical character of Maurice Devane, a sufferer of depression and degradation whose mental state leads from resolution to recovery from guilt-ridden thoughts and spiritual despair. Clarke himself suffered a mental breakdown and used the composition of this long poem for inward analysis and catharsis.

Clarke went through a faith-enhancing journey in his early poetry, but a journey that also raised questions faith and its influence on the poet. Maurice Harmon comments that Clarke often writes of the "burdens of morality and his own sinful nature." ${ }^{5}$ That conflict is all too common for a man struggling between light and dark, piety and sin, faith and reason. Clarke's poetry pays attention to the conflicts in religion as well as to the sense of responsibility sensed by a writer who experiences both suffering and atonement, and who feels both salvation and redemption. Clarke uses his poetry not only to elevate a religious sensibility but also to question and examine its nature.

Clarke's poetry is often immediately concerned with Free State Ireland of the 1920 and 1930s. This was a period when the censorship laws were imposed upon writers who tended to engage the subjects of religion, politics, and sexuality. Clarke came to believe that these laws were the direct result of the direct influence of the Catholic hierarchy in Ireland. Susan Halpern observes that

the younger generation of writers were $[s i c]$ nearly all Catholics, and the Catholic Church in the new Ireland had done what it could to alienate them. Close behind the general censorship lay the general asceticism, Puritanism or Jansenism.... There was only one way a writer could be meaningful in post-revolutionary Ireland: by addressing himself to the actual problems of the rural population and the Catholic majority. ... ${ }^{6}$

5. Harmon, p. 77

6. Susan Halpern, Austin Clarke: His Life and Works (Dublin: Dolmen Press, 1974), p. 17. 
Owing to the triumph of nationalism, Ireland came to focus internally on domestic problems. The writers of Clarke's generation began to do the same with their writing. While they attacked the imitators of the English, they also criticized corrupt politicians, class pretensions, and, of course, the Irish church.

The church and the new middle class joined forces, and the effect that this had on artists and intellectuals was far from positive. "The new sense of alienation, following on the heels of the disturbing Civil War greatly endangered the position of the artist, making it increasingly difficult for him to maintain a sane and healthy relationship with his material."' As the Irish Free State Official Handbook (1932) put it, since end of the eighteenth century concessions were gradually granted by parliament to the Catholic majority — most important, the right to vote in parliamentary elections: "Most of the remaining restrictions were ended by the Emancipation Act of 1829, which allowed Catholics to sit in Parliament." ${ }^{8}$ The Handbook noted further the increasing sway of Catholicism: "The Census of 1926 shows the numerical strength of the principal religious denominations in Saorstát Éireann as follows: Religion: Catholics, Total: 2,751,269, Percent of Population: 92.6." Even before 1921, the Catholic church had come to dominate all levels of education and government in Ireland. In Clarke's narrow world, that influence was difficult to escape.

Given the autobiographical roots of his poetry, it is obvious that Clarke was deeply affected by the Catholicism of Free State Ireland, as Maurice Harmon has noted: "[Clarke] was born into a family that combined the narrow conformity of Irish Catholicism with the repressive respectability of late Victorianism."10 When Clarke was growing up, he went to Sunday Mass, to weekly confession, and was sent by his parents to Catholic schools, including Belvedere College, where he took the same annual retreats and heard the same sermons that Joyce describes in A Portrait of the Artist as a Young Man (1916). Clarke's introduction to the Catholicism of his schooling presented him with a terrifying and judgmental biblical God whom students were taught to to fear while living lives of restriction and privation. But Clarke's schooling was also balanced by trips to the countryside full of "freedom, discovery, stories and adventure." 11 Religion was not always exclusively threatening, and Clarke "enjoyed the various ceremonies and rituals of the church." $12 \mathrm{He}$ shared devotions with his sisters, one of whom later became a nun. One of his favorite yearly devotions was the ritual of

7. Halpern, p. 19.

8. Saorstát Éireann Irish Free State Official Handbook (Dublin: Talbot Press, 1932), p. 70.

9. Irish Free State Official Handbook, p. 70.

10. Harmon, p. 16.

11. Harmon, p. 17 .

12. Harmon, p. 17. 
visit to seven churches on Holy Thursday. In his autobiography Twice Round the Black Church (1962), Clarke recalls that piety:

Every new aspiration, every indulgence of which she heard, whether attached to some special devotion or gained by visiting a shrine, whether symbolized by metal or scapular, drew her. I, too, had already felt a mysterious power of those scapulars which we wore, the brown scapular of St. Francis, the red, the white, the black one for the dead, the blue for the Blessed Virgin ... so soon the little holy picture printed on the white side became blurred from constant wear and perspiration. ${ }^{13}$

Here we see Clarke devoted to his religion and proud of its influence. All the while, however, he was questioning such rules and devotions.

Like Ireland itself, in the latter nineteenth century the Irish church had gone through significant changes and reforms that made the influence of the church more pronounced. Most bishops at the time had zealously promoted pastoral reforms no matter what their educational or political views were. This resolution of power moved the church into the twentieth century. The number of priests in Ireland had grown rapidly, and their prodigious energy had also grown to promote reformed conduct and learning through prayer and sacrament. Emmet Larkin writes that

In extending their increasing zeal and piety to the laity the clergy centered their attention on the sacraments, and especially on the sacraments of penance and Holy Eucharist. Confession and communion, which usually had been associated with a practicing Catholic's Easter duty in pre-famine Ireland, now became much more frequent. ${ }^{14}$

Clarke had grown up in an increasingly pious religious climate. By the time he was old enough to begin to comprehend his own family's Catholicism, he found himself in an Ireland filled with pious devotions - the rosary, perpetual adoration, novenas, benedictions, vespers, and pilgrimages to shrines. Irish Catholicism came to emphasize to a communalization of the laity by means of the regularized practice of pious public exercises. Larkin writes, "Pastoral gains thus made were consolidated by the introduction of a whole series of devotional exercises designed not only to encourage more frequent participation in the sacraments but to instill veneration by an appreciation of their ritual beauty and intrinsic mystery." 15

13. Austin Clarke, Twice Round the Black Church: Early Memories of Ireland and England (London: Routledge and Kegan Paul, 1962), p. 47.

14. Emmet Larkin, The Historical Dimensions of Irish Catholicism (New York: Arno Press, 1976), p. 644 .

15. Larkin, $\mathrm{p}, 645$. 
Unfortunately, confession became a source of pain for Clarke. His eventual disillusionment with the church arose not just from his struggles with faith but also from his questioning of such rituals. Clarke's childhood innocence was disturbed especially during his first confession when he was questioned about the sin of masturbation. Clarke had no understanding of this sin, but, out of fear and desperation, he finally admitted to the act, culminating in religious shame. The devotional side of Irish Catholicism fascinated Clarke as a child, but as he aged, prayer books, scapulars, holy pictures, and other devotional tools lost most of their religious meaning. Soon, as if to wonder how the reward of an afterlife might be connected to public and shaming displays of devotion, he was asking questions like, "Why should our blessed truth / Be measured by the mile?"16 It was difficult was for Clarke to ignore such an important aspect of Irish life as religion, especially in a country that prided itself on its religious devotion. As John McAuliffe writes, during Clarke's lifetime,

The city of Dublin is primarily defined by the increasingly powerful presence of Catholicism. The church dominates Ireland's cultural discourse as well as its political life and physical landscape. There is not much sign of a counterculture-with the passing of Yeats' generation, [Clarke] describe[s] the city's literary culture as impoverished and in constant retreat. ${ }^{17}$

The passing of Irish Revival writers gave Clarke the opportunity to take on the role of satirist in order to speak of both shame and complaint. He "consistently refers to urban life and contemporary political and religious intrigue-his satires will be a reliable map to the changing state." 18 Thomas McCarthy writes that "in the 1950s faith had a vibrant street-life. Clarke follows the life around the Free State like a well-rehearsed heckler." ${ }^{19}$ After all, Clarke had been indoctrinated into the Catholicism early on in a country that used its religion for political and social strength. He came to question the tenets of Catholicism in order to find some sort of independence. While attending primary and secondary school in Limerick and Dublin, he discovered works like Arnold's Literature and Dogma, Renan's Life of Jesus, and the writings of Francis Newman and Friederich Nietzsche-all writers who "emphasized the importance of rational inquiry and were slow to accept orthodox views." 20 Unfortunately for Clarke, when those

16. Austin Clarke, Collected Poems (Dublin: The Dolmen Press, 1974), p. 203; hereafter cited parenthetically, thus: ( $C P$ 203).

17. John McAuliffe, "Urban Hymns: The City, Desire and Theology in Austin Clarke and Patrick Kavanagh," in Critical Ireland: New Essays in Literature and Culture, ed. Alan Gillis, Kelly Aaron (Dublin: Four Courts Press, 2001), p. 166.

18. McAuliffe, p. 170 .

19. Thomas McCarthy, Gardens of Remembrance (Dublin: New Island Books, 1998), p. 196.

20. Harmon, p. 17. 
books were discovered by his mother, they were deemed blasphemous and quickly discarded. This act reveals the strict religious climate that Clarke dealt with in his family and personal life as well as the censorious aspects of religiosity that Irish Catholicism had embraced.

Dealing with such private and public constraints was not an easy task, yet Clarke often joked about how it soon became clear to him that something had to be done about the conflict between faith and intellectual freedom in his own life and in the life of Ireland. The title of his first memoir, Twice Round the Black Church comes from a story that he was told as a child. The Protestant "black church"-St. Mary's Church in Dorset Street, Dublin—was something that Clarke feared for many reasons, including its ominous stature in the moonlight. Clarke writes, "As children, we were told that anyone who ran around the church three times after dark would meet the Devil himself on the third round, but none of us had the courage to test the legend" (TRBC 22). Clarke's bravery extended to running only two times around the church, as if he were taunting the Devil or wanting to question the sinful side of mortality, and then suddenly had changed his mind at the moment of truth.

This represents the thought process of the poet. Clarke pondered the domination of the Irish church over the mental and physical landscape of his upbringing. In the poem "Ancient Lights," Clarke looks at the natural light of his autobiographical speaker and challenges the placement of rules, written by the church, on his involvement in Irish society.
When all of us wore smaller shoes
And knew the next world better than
The knots we broke, I used to hurry
On missions of my own to Capel
Street, Bolton Street and Granby Row
To see what man has made. But darkness
Was roomed with fears. Sleep stripped by woes
I had been taught, beat door, leaped landing,
Lied down the bannisters of naught. (CP 199)

This first stanza of "Ancient Lights" is concerned with the relationship of children to their religious upbringing. The "next world" is contrasted with the reality of life, which a child is hardly aware of or fully understands. The divinity of the church is then contrasted with the sights in Dublin's shopping streets: "To see what man has made," almost as if Clarke is asking whether we made the religion or did it make us. When he breaks the laces on his shoes, Clarke's speaker is also concerned with the other world and the "thou shalt nots" of the Ten Commandments. There is also a double meaning in the word "missions," referring not just to the Catholic missions, but also to the children being sent on 
errands with rewards for good deeds. The last half of Clarke's stanza presents the fear and darkness that the church and its confessional represent. The "woes," about which he has "lied," send him on a banister ride of superstition and fear, a reality that he feels he cannot easily escape.

The next four stanzas consider the speaker's terror, especially in the confessional where the sins of the flesh are admitted and then thought of as false. Then a lesson is learned about trying to prevent two sparrows from devouring a caged bird and this incident echoes the guilt from not being able to help the bird as well as the morality and despair the speaker sees in his own life. Clarke writes that "Pity / Could raise some littleness from dust," a statement is "a striking thought that grants agency and a sacrilegiously godlike power of resurrection to the young child." 21 The last two stanzas become highly symbolic for the reader when we see the boy taking refuge from the rain in the doorway of a Protestant church-the same Black Church in the title of his memoir.

$$
\begin{aligned}
& \text { Still, still I remember the awful downpour } \\
& \text { Cabbing Mountjoy street, spun loneliness } \\
& \text { Veiling almost the Protestant church, } \\
& \text { Two backyards from my very home, } \\
& \text { I dared to shelter at locked door. } \\
& \text { There, walled by heresy, my fears } \\
& \text { Were solved. I had absolved myself: } \\
& \text { Feast-day effulgence, as though I gained } \\
& \text { For life a plenary indulgence. } \\
& \text { (CP 200) }
\end{aligned}
$$

Clarke finally does absolve himself. Of this moment, McAuliffe observes, the location is symbolic, on a busy, rainy street, at the door of a church, like Martin Luther before him. His use of sacramental language grants the church an almost bridal appearance, the rain baptizes his new fearlessness. ${ }^{22}$ The confessions of the last stanza in "Ancient Lights" are connected to the religious implications of the Catholic Mass, its dominance over the city and the "moment of crisis when powerful forces test the identity of the individual." 23

Irish Catholicism had a continual influence on Clarke's poetry. The notions that enter a boy's mind are never truly abandoned in adulthood, especially if they drive the mature poet's concerns. From his earliest work, The Vengeance of Fionn (1917), to one of his last, Mnemosyne Lay in Dust (1966), the implications of history, religion, and artistic conflict remain in the forefront of Clarke's contemplations: "Clarke's first legend articulates the beginning of his long drama of

\footnotetext{
21. McAuliffe, p. 172.

22. McAuliffe, p. 172.

23. McAuliffe, p. 173.
} 
conscience and inner conflict so clearly displayed in Mnemosyne Lay in Dust... [The] narrative registers his sense of frustrating repression." ${ }^{24}$ As his career unfolds, Clarke's self-knowledge grows with every passing poetic thought. Likewise, his understanding of the influence of religion in Ireland becomes more and more evident, even through his anxiety over the consequences of his chosen art. All along his choice of subject matter with which he tends to identify also grows. Clarke moves ahead with caution, questioning religion and desiring a return to pagan ritual, all the while realizing his quest and questioning ideals..$^{25}$ Hugh Kenner has written that Clarke's verse is "packed and evasive because it must achieve its air of control without recourse to the declamatory tones of certainty ... Ireland's religion thwarts, but not for instance that Ireland 'would be better without its religion.' (Reflect that Ireland is unimaginable without its religion.) ${ }^{26}$ Many other Irish writers besides Clarke realized the religious restraints at work in early twentieth-century Ireland Ireland. For example, of orthodox Christian morality W.B. Yeats wrote in A Vision (1926) that

These things are testified to from books that are outside human genius, being miraculous, and by a miraculous Church, and this church, as the gyre sweeps wider, will make man also featureless as clay or dust. Night will fall upon man's wisdom now that man has been taught that he is nothing. ${ }^{27}$

We see such themes in Clarke's poem "Repentance," which uses the usual darkness to give emphasis to "a spiritually degrading culture which is founded on primal emotions such as guilt and fear, and given practical expression in the revocations of an abstract moral system." 28
No story handed down in Connaught
Can cheat a man, nor any learning
Keep that fire in, turn his folly
From thinking of that book in Heaven.
Could I unbutton mad thought, quick-save
My skin, if I were caught at last
Without my soul and dragged to torment,
Ear-drumming in the dreadful place
Where the sun hides in the waters? $\quad(C P$ 186-87)

24. Thomas Dillon Redshaw, "The 'Dominant' of Memory in Austin Clarke's The Vengeance of Fionn (1917)," Études Irlandaises, 10 (1985), 87.

25. Redshaw, 88-89.

26. Hugh Kenner, A Colder Eye: The Modern Irish Writers (Baltimore: Johns Hopkins University Press, 1983), p. 247.

27. W. B. Yeats, A Vision (New York: Collier Books, 1973), p. 274.

28. Daniel J. Murphy, "The Religious Lyrics and Satires of Austin Clarke," Hermathena, 122 (1977), 49 . 
This last stanza of "Repentance" presents a deep internal struggle that is reinforced by the "contortions of language and rhythm, and the highly distinctive rhetoric," a typical choice for the meditational style of Clarke's religious verse. ${ }^{29}$ Clarke is still searching for a new and growing consciousness in Catholic truth. It is as though the fear of torment over having unorthodox religious thoughts becomes more prominent than faith because of faith's problematic nature. Clarke's childhood faith is the one thing he is trying to abandon; yet he remains filled with torment over how he will achieve this abandonment as well as over the consequences of an action.

An odd tension arises in Clarke's poetry. Although he never intended to become a "Catholic poet," he is as strongly drawn to investigating his Catholic conscience as to the freedom to explore Irish culture. This tension is quite prominent in Pilgrimage and Other Poems, even though Clarke trades criticism of the negative aspects of the Irish church for reverence and adoration for the historical practices of the church. The problem of spiritual fulfillment remains present in Pilgrimage, but, as Gregory Schirmer observes, "these poems assert with great conviction and force the humanistic appreciation of man's intrinsic worth and freedom that informs all of Clarke's work." "Celibacy," the poem that was included in Kilmer's anthology, is an early satirical poem by Clarke that examines the conflict between human sexuality and spiritual discipline-a conflict notable in Ireland since the time of the medieval abbeys and hermit-caves.

On a brown isle of Lough Corrib

When crowds were bare as branch

And water had been thorned

By colder days, I sank

In torment of her side;

But still that woman stayed,

For eye obeys the mind.

Bedraggled in the briar

And grey fire of the nettle,

Three nights, I fell, I groaned

On the flagstone of help

To pluck her from my body;

For servant ribbed with hunger

May climb his rungs to God. (CP 155)

29. Murphy, 49.

30. Gregory Schirmer, The Poetry of Austin Clarke (Notre Dame: University of Notre Dame Press, 1983), p. 23. 
"Celibacy" is in a confessional style, much like other poems in Pilgrimage. Of Clarke's first-person speaker, who confesses to the sexual temptations that afflict him, Harmon writes, "The tone of the poem seriously reflects his predicament but with a suggestion of mockery in some of its exaggerated language." ${ }^{11}$ Although "Celibacy" focuses on the subject of temptation by a beautiful and persistent woman, it lacks sensuality. The lines are short and pointed and full of alliteration and assonance. The use of the shorter line befits a "brief confessional declaration" more than the description of sexual temptation. ${ }^{32}$ The speaker resorts to rigid self-discipline to curb his body and, therefore, his soul because "eye obeys mind." G. Craig Tapping writes that Clarke's speaker is in a "self-imposed exile and from the denial of his natural desires," and so, "His very hunger invites and creates of itself hallucinations instead of the desired gift of atonement." 33

The subject of strict Irish Catholicism is often on the mind of the poet. The influence of the church reaches throughout the country, and Clarke sees it as a hindrance to the Celtic heritage that has been abandoned for modern religion. In "The Blackbird of Derrycairn," the Clarke puts his complaint into the voice of a blackbird and creates a monologue on the rewards of the natural and pagan life.

Stop, stop and listen for the bough top

Is whistling and the sun is brighter

Than God's own shadow in the cup now!

Forget the hour-bell. Mournful matins

Will sound, Patric, as well as nightfall

Faintly through mist of broken water

Fionn heard my melody in Norway.

He found the forest track, he brought back

This beak to gild the branch and tell, there,

Why men must welcome in the daylight. (CP 203-04)

Clarke adopts the poem's imagery and themes borrow from the Fenian lyric "Lon Doire an Chairn." In these first two stanzas, the poet reaches back into history to account for his anti-church message. The blackbird sees the traditions of Christianity as dated, filled with discipline rather than freedom, and confining and mournful. Clarke shows a blackbird feeling a breeze that allows for an open and conscious decision to choose a closer communion with nature and, therefore, an acceptance of Ireland's Celtic heritage. In these poems, Clarke

31. Harmon, p. 66.

32. Harmon, p. 66.

33. G. Craig Tapping, Austin Clarke: A Study of His Writings (Dublin: Academy Press, 1981), p. 58. 
often reaches back into Celtic tradition in order to resist the modern Irish church and its rules that emphasize the physical gestures of religion rather than mental or spiritual ones.

The issues of religious and governmental politics necessarily enter Clarke's poetry. Clarke sees politics and religion as closely related, especially considering that the Censorship Act of 1929 was encouraged by the Irish clergy. In his poem "Penal Law," the poet sarcastically comments on attempts to suppress thought and intellect, freedom and education.

Burn Ovid with the rest. Lovers will find

A hedge-school for themselves and learn by heart

All that the clergy banish from the mind,

When hands are joined and head bows in the dark.

$(C P 189)$

Clarke's title refers to the Penal Laws enacted against Irish Catholics after 1691. Clarke feels that censorship in the twentieth century is just as closed minded as the old Penal Laws. Irish Catholics started the hedge schools when they were denied education. Clarke links their desire to the contemporary desire to learn of love. If the twentieth-century Irish church will not allow conversations of love, then lovers will find a new place to meet and to learn it "by heart" through instinct and discovery. Maurice Harmon writes that

The clergy banish love, but lovers become its devotees, finding a religion of love, with hands joined and heads bowed. The attitudes of prayer are appropriated to describe the lovers. The contrast ... is between heart and mind, between clerical rules and natural feeling. ${ }^{34}$

The wonder of this short poem lies in Clarke's belief that love cannot be contained or dictated by religion. Clarke challenges the clergy and censors to do their worst. Love will not be contained because it is a religion unto itself, a spiritual existence created by the anointed lovers. In "Penal Law," the play of religious imagery and love-filled metaphors shows a confrontation between two systems of feeling or two ideologies that coexist while also repelling each other.

Two more poems look at the contradictory nature of religion: "Marriage" and "Celebrations." Both of these poems are included in Ancient Lights (1955), a collection whose title refers to the light of the word and one that is old and dated. The light is a metaphor for Clarke's resistance to clerical restrictions and refers to a past filled with a mythology that helps to clarify the present. Ironically, Clarke once again identifies the contradictory nature of the church in an Ireland that has traded self-reliance and liberation from oppressive religiosity

34. Harmon, p. 86. 
for prosperity. The title of the first poem in Ancient Lights, "Celebrations," is also fittingly ironic, just as are the first lines of the opening stanza:

Who dare complain or be ashamed

Of liberties our arms have taken?

For every spike upon the gateway,

We have uncrowned the past:

And open hearts are celebrating

Property of church and state

In the shade of Dublin Castle. (CP 195)

Linked to the Eucharistic Congress of 1932 in Dublin, "Celebrations" satirizes the complacency of the Irish public that celebrates the church without understanding its faulty past. There is nothing to celebrate, but the public still celebrates the triumph of the church. Clarke's ambivalent tone controls the subject as well as the imagery: "The religious imagery of the poem is aggressively yoked to Clarke's declaration that Ireland's theocracy is corrupt and self-seeking, adding a blasphemous intimation to the image of 'open hearts." 35 The final stanza expresses Clarke anger at the smug piety of Free State Ireland.

Let ageing politicians pray

Again, hoarding recount our faith,

The blindfold woman in a rage

Condemn her own for treason:

No steeple topped the scale that Monday,

Rebel souls had lost their savings

And looters braved the streets. (CP 195)

Free State Ireland has replaced faith with greed, and Justice, still blindfolded, looks upon her people as treasonous. Originally, Britain had accused the 1916 rebels of treason, and now the rebels' own country is guilty of it. The church's influence now dominates Irish life, and the rebels have been stripped of their spirit and traded in for clerical recognition and religious conformity.

Similarly, the poem "Marriage" looks at a contradiction in the rules of the church. Clarke focuses on the injustice of Catholic teachings about contraception: "The rhythm method of birth control, based on the women's fertility cycle, is not only unreliable, resulting in more children than the parents can easily afford, but subverts the grace of the marriage sacrament." 36 In the first few lines of "Marriage," Clarke uses humor and double entendre to examine seriously the predicament of the faithful Irish family:

35. Tapping, pp. 175-76.

36. Harmon, p. 142. 
Parents are sinful now, for they must whisper

Too much in the dark. Aye, there's the rub! What grace

Can snatch the small hours from that costly kiss? (CP 196)

Soon we see the religious and sacramental point of the "Marriage" as Clarke balances the honoring of marriage with a partly comic conclusion. Clarke's intense desire to condemn the authoritarian Irish church turns, by way of political and religious debate, into a desire for the reform of that church. The telling satire in this poem comes from Clarke's movement between perceiving the the seriousness of marriage and seeing that inflexible rules have made it into a joke.

Those who slip off the ring, try to be chaste

And when they cannot help it, steal the crumbs

From their own wedding breakfast, spare expense

And keep in warmth the children that they have nourished.

But shall the sweet promise of the sacrament

Gladden the heart, if mortals calculate

Their pleasures by the calendar? Night-school

Of love where all, who learn to cheat, grow pale

With guilty hope at every change of moon! (CP 196)

"Inscription for a Headstone" is one of Clarke's most straightforward poems about Ireland's problems with religion. It is a poem in memory of James Larkin, the labor leader who was involved most famously in the Dublin Lock-out of 1913. Larkin's social ideas were later be adopted by the church in order "to obscure the issues of economic unrest." ${ }^{37}$ Clarke describes the scenes of bodies being taken away in ambulances during the Lockout, but then ends the poem by protesting of the irony of Larkin's enduring memory:

Such fear can harden

Or soften heart, knowing too clearly

His name endures on our holiest page,

Scrawled in a rage by Dublin's poor. $\quad(C P$ 202)

There is a muted sadness to this poem, even though the themes allow Clarke's political and religious satire room to grow. Clarke questioned the exploitation of the poor in Ireland owing to policies nurtured by a church that he viewed as a corrupt and controlling institution.

At the end of his career, Clarke had relegated himself to celebrating the "sins" of his childhood. By way of bitter satire, Clarke had found the liberty to deal with his early religious guilt in a mature and direct fashion. Clarke had grown to tackle scarring and frightful issues, and only this newfound freedom 
could return the poet to the realism of life instead of the allurements of spirituality and allegorical nature of religious guilt.

The combination of Victorian prudery and Jansenistic Catholicism that shaped [Clarke's] growing years made him reticent about earthly matters. It is true that he spoke out strongly at times against moral censure and bemoaned its stifling effects on human nature, but he found it hard to deal with directly in his imaginative writings. Only in his later poetry did he find the freedom to treat sexual experience realisticallly. ${ }^{38}$

Such conflicts between the individual and society drove Clarke to create. Since his society was post-Tridentine Catholic Ireland, the poet often exchanged the judgmental ideals of the accepted authority for an imaginative faith in the mythological, romantic, and medieval. Clarke identified with the distant pastincluding that of the Celtic church-because he felt that the religious and social problems of Ireland would probably last through the twentieth century and that religion would continue to domineer the Irish artist who pondered such problems.

Indeed, it does seem that Austin Clarke holds his place among Catholic poets and writers because, while he struggles often with his religion, it still defines him. Clarke's Catholicity may be distinguished from the Irishness of his character and art. Many Irish of his time used Irish Catholicism as a way to give homage to the greatness of their world, the blessings of their surroundings, and the identity of their nation. Yet, Clarke went further and often used religion to see beyond his country and his art. He struggled for a new definition of life and memory within a country that had idealized its Catholicism and again embraced its Irishness in order to seek autonomy and escape England's rule. Clarke thought that Irish poetry, while driven by religion and politics, held much more truth and thought than simply what his fellow countrymen thought of as patriotism. Poetry was a necessity and one that was just as important as religion and independence.

To begin to understand Ireland one must understand Ireland's Catholicism. In Clarke's instance, one must understand poetry in order to question the Irish religious character. Clarke's poetry helps the reader get closer to the truth and the character of Irish religious experience. In Twice Round the Black Church Clarke quoted Ibsen to give "us a definition of poetry which seems appropriate to our needs . . Poetry-'tis a Court / Of Judgment on the soul." Clarke's inclusion in an anthology of Catholic poets is justified for not only his adora-

38. Harmon, p. 135. 
tion of poetry, but also his questioning of the spiritual side of Catholicism's very inspirational nature. In such poems as as "Celibacy," "Penal Law," "Marriage," "Pilgrimage," "Repentance," and "Inscription for a Headstone," Clarke confronts the issues of faith and politics as focal points in his Catholic identity. and in Ireland's. Clarke's poetry fulfills his spiritual aspirations, even though he sometimes suspected otherwise. His poetry is that of an Irish Catholic manqué. Religion dominated his thought and spurred him to ponder the larger questions of faith-church involvement in secular life, the sacraments, and spiritual fulfillment. Clarke's difficult poetry is almost identical his difficult Catholic faith: they both provide direction, adoration, experiment, and challenge.

- UNIVERSITY OF DUBUQUE 